THE AMERICAS

66:3/January 2010/305-310 COPYRIGHT BY THE ACADEMY OF AMERICAN FRANCISCAN HISTORY

\title{
Evangelization as PeRformance: Making Music, Telling Stories
}

$\mathrm{I}$ n the 1970s two important trends in Latin American history came into conjunction. The older of these was the study of the evangelization of the natives of the New World. The evangelization largely occurred at the hands of the regular clergy: Franciscans, Dominicans, and Augustinians. Nevertheless, there were significant numbers of secular priests who also engaged in the mission, but they did not leave the editorial legacy of the religious. The second trend which emerged was the study of the native peoples, but with a very important new consideration. While earlier historians had been contented to write basing their histories on the Spanish language documentation, in the 1970s a new generation of scholars versed in Nahuatl, Maya, and other native languages, began to look at themes utilizing native language documentation. The confluence of these two trends was the use of native language documentation to study the evangelization.

While civil records using native languages are plentiful (wills, contracts, municipal records, and notarial records in general), didactic works dedicated to the missionary effort clearly constitute an equally significant part of the extant documentation. Consequently the utilization of these sources became the challenge confronting both scholars focused on the history of the native peoples as well as those looking at the evangelization and the general cultural impact of the Europeans on the native peoples. While not all of the articles in this collection draw immediately on native texts, they all draw heavily upon native popular traditions and go beyond to look at the point of interface between the native traditions and the evangelization.

Some of the landmark works which have paved the way for this new wave of scholars includes the work of James Lockhart, Louise Burkhart, and Barry Sell. Lockhart, of course, initiated the practice of utilizing the native language documentation to better reconstruct the history of the early colonial period. His work, The Nabuas After the Conquest is both a study of the Nahua themselves and an apologia for the "new philology:" the identification of language trends to help document larger cultural changes. ${ }^{1}$ Lockhart also briefly discusses the use of theatre to assist in the evan-

1. James Lockhart, The Nabuas After the Conquest (Stanford: Stanford University Press, 1992) 
gelization, and how those works can also help to document language change. Yet he concluded that it was too early to make any broad conclusions. ${ }^{2}$

Scholars began looking at Nahuatl language performance pieces in the middle years of the last century. After the groundbreaking work of scholars in the late nineteenth century, such as Joaquín García Icazbalceta and Francisco del Paso y Tron$\mathrm{coco}^{3}$ three North Americans, Byron McAfee, Robert H. Barlow, and John H. Cornyn, became interested in the genre. The three both worked independently and also collaborated with one another in early research into the performance of Nahuatl language theatre in the early colonial period. ${ }^{4}$ Fernando Horcasitas, one of the pillars of Nahuatl studies in Mexico in the mid-twentieth century, dedicated much of his life to recovering Nahuatl theatrical pieces. His efforts to publish those were cut short by his death. Only one volume of his work appeared in print, in $1974 .^{5}$ At just about the same time, several of the works collected by McAfee and Cornyn were then published by Marilyn Ekdahl Ravicz in her book Early Colonial Religious Drama in Mexico. ${ }^{6}$

In more recent years, Barry D. Sell and Louise Burkhart have taken up the search for and study of Nahuatl drama from the colonial period in their three-volume study Nabuatl Theater. The first volume presents works from the early colonial period, including some collected by McAfee, Barlow, and Cornyn, and others. The second volume focuses on works dealing with the Virgin of Guadalupe, while the third looks at Golden Age dramas translated from Spanish to Nahuatl in the early seventeenth century. Volume four of the collection presents scripts from the eighteenth century, three of which have never been published before. Sell and Burkhart have gone a long way in presenting the texts to us and their implications on the cultural environment in which these texts and productions existed. Yet what is lacking is the more mundane, quotidian impact of theater and other performance art on the colonial environment. The articles in this collection take us one step beyond the texts, to see how those texts and musical compositions functioned in everyday life.

While the literature regarding theatrical productions has grown notably in recent years, there has been significantly less work on music as a tool for evangelization,

2. Lockhart, The Nahuas, p. 410.

3. See Joaquín García Icazbalceta, "Representaciones religiosas en México en el siglo XVI," In Fernán González Eslava, Coloquios espiritules y sacramentales (Mexico: Antigua Librería, 1877). Paso y Troncoso edited five plays as part of his series Biblioteca Nabuatl, published in Florence between 1899 and 1907.

4. John F. Schwaller, Guide to Nabuatl Language Manuscripts Held in U. S. Repositories (Berkeley, Academy of American Franciscan History, 2001), p. 44. Barry D. Sell and Louise Burkhart, Nahuatl Theater, 4 vols. (Norman, OK: University of Oklahoma Press, 2004-2009), vol. 1, pp. xii-xiii.

5. Fernando Horcasitas, El Teatro Nabuatl: Epocas Novobispana y Moderna (Mexico: Universidad Nacional Autónoma de México, 1974).

6. Marilyn Ekdahl Ravicz, Early Colonial Religious Drama in Mexico (Washington, DC: Catholic University of America Press, 1970). 
at least for the core regions. The only notable publication in the sixteenth century was the same as the twentieth century, Bernardino de Sahagún's Psalmodia Christiana. $^{7}$ The noted Franciscan, Sahagún, sought to take native songs from the preColumbian tradition, and give them new lyrics in keeping with Christian themes and theology. While the work is a priceless glimpse into the musical culture of the evangelization, all we have are the lyrics; we do not have the music itself. Similarly the largest corpus of pre-Columbian songs, the Cantares mexicanos, is a collection of the lyrics from ancient songs, along with a few from the postconquest era, but without the music. ${ }^{8}$ The cantares manuscript does, however, provide drum rhythms and chant forms, but in a format which has not yet been completely deciphered by modern scholars.

Music historians have paid more close attention to the use of music in the missions than have ethnohistorians or social and cultural historians. Nevertheless, the bibliography is not a long one. A pioneer and towering figure in the field of colonial Latin American music history is Robert Murrell Stevenson. He is perhaps best known for Music in Aztec and Inca Territory and Music in Mexico: A Historical Survey. His work also considered the Iberian origins of New World music in his books Spanish Cathedral Music in the Golden Age and Spanish Music in the Age of Columbus. ${ }^{9}$ Beyond this, Stevenson also wrote numerous articles on colonial Latin American music, especially regarding the use of music in the conversion. ${ }^{10}$

Among Spanish language authors, Jesús Estrada has been the most significant music historian of Mexico, and contributed important studies. Two works stand out. Estrada's short study of Música y músicos de la época virreinal focuses mostly on music in the metropolitan region, and little on the use of music as a conversion tool. The work he edited, La música de México, does contain contributions which illuminate the use of music in the evangelization, in particular an article by José Antonio Guzmán Bravo. ${ }^{11}$ Lourdes Turrent provided a good insight into the use of music as a tool of conquest and evangelization in her book, La conquista musical de México. ${ }^{12}$

7. Bernardino de Sahagún, Psalmodia Christiana (Christian Psalmody), translated by Arthur J. O. Anderson (Salt Lake City: University of Utah Press, 1993).

8. Cantares mexicanos [facsimile edition] (Mexico: Universidad Nacional Autónoma de México, 1994). John Bierhorst published a controversial translation of the cantares. The palcography of the original manuscript is extremely well done, but the translation was based upon a hypothesis that the songs represented a Mesoamerican form of the Plains Indian "ghost dance." John Bierhorst, Cantares mexica nos: Songs of the Aztecs (Stanford: Stanford University Press, 1985).

9. Stevenson, Aztec and Inca (Berkeley, CA: University of California Press, 1968), Stevenson, Music in Mexico (New York: Crowell, 1952); Stevenson, Spanish Cathedral Music (Berkeley, CA: University of California Press, 1961); Stevenson, Music in the Age of Columbus (The Hague: M. Nijhoff, 1960).

10. Robert Stevenson, "Written Sources for Indian Music before 1882," Ethnomusicology, 17:1 (Jan. 1973), pp. $1-40$.

11. Jesús Estrada, Música y músicos de la época virreinal (Mexico: SepSetentas, 1973); Jesús Estrada, ed., La música de México (Mexico: Universidad Nacional Autónoma de México, 1986), 2 vols.

12. Lourdes Turrent, La conquista musical de México (Mexico: Fondo de Cultura Económica, 1993). 
Yet, others have also investigated the use of music in the evangelization. Most recently Gary Tomlinson has written on the native music tradition at the moment of the arrival of the Europeans. ${ }^{13}$ The musical traditions in the missions have also served as a theme for research. For example, Larry Warkentin provided an overview of indigenous music in the California missions in his article. ${ }^{14}$ Most recently, John Koegel has written a long article on the use of music in the evangelization of the northern frontier region of New Spain. ${ }^{15}$ Koegel's notes are particularly rich in surveying the existing literature on the use of music in the missions. Geoffrey Baker has recently published a study of the musical culture of Cuzco. This work goes far beyond looking at music as a missionary tool, and concludes that music was a pervasive element in the city, reaching far beyond the cathedral and churches of the city and having an important native component. ${ }^{16}$ Yet, as noted, the field has remained largely open with only a few articles appearing in any given year, and few major works of synthesis.

The last area of the evangelization to be considered was the first studied historically and that was the indoctrination provided to natives by the missionaries. The bibliography of this activity is long indeed. There has been a revolution of sorts in the study of the evangelization thanks to the increasing familiarity of scholars with the native languages which were targeted by the missionaries as the vehicles for their teachings. The seminal work in this regard is Louise Burkhart's The Slippery Earth. ${ }^{17}$ That study focuses on the negotiation of terminology between the missionaries and the neophytes as the Spanish attempted to walk a fine line between adopting Nahuatl terms for Christian purposes and the translation of Christian concepts into Nahuatl.

Many of the documents composed by the missionaries have now been studied by scholars to better come to grips with the nuances of the evangelization. James Lockhart and Frances Karttunen provided the essential groundwork as they identified the linguistic changes through which Nahuatl passed the longer it was confronted with Spanish, the roots of the "new philology."18 Other studies have looked at particular genres and specific works, such as the study of the Confession-

13. Gary Tomlinson, The Singing of the New World: Indigenous Voice in the Era of European Contact (Cambridge: Cambridge University Press, 2007).

14. Larry Warkentin, "The Rise and Fall of Indian Music in the California Missions," Latin American Music Review/Revista de Misica Latinoamericana, 2:1 (Spring-Summer, 1981), pp. 45-65.

15. John Koegel, "Music and Christianization on the Northern Frontier of New Spain," in Calvin B. Kendall, Oliver Nicholson, William Phillips, and Marguerite Ragnow, editors, Conversion to Christianity from Late Antiguity to the Modern Age: Considering the Process in Europe, Asia, and the Americas (Minneapolis, MN: Center for Early Modern History, 2009), pp. 293-332. 2008).

16. Geoffrey Baker, Imposing Harmony: Music and Society in Colonial Cuzco (Durham, NC: Duke University Press,

17. Louise Burkhart, The Slippery Eartb: Nabua-Christian Moral Dialogue in Sixteenth-Century Mexico (Tucson, AZ: University of Arizona Press, 1989)

18. Lockhart, The Nabuas, pp. 261-325. 
ario mayor y menor of Bartolomé de Alva studied by Barry Sell and myself. ${ }^{19}$ One of the more interesting features of the original work was the recognition of preColumbian religious traditions and how these might best be countered by the missionary. An even more pointed work was composed by Hernando Ruiz de Alarcón. This parish priest from Central Mexico developed a concern over the continuation of native religious traditions even into the seventeenth century, and so wrote his guide to assist local curates in the extirpation of idolatry. ${ }^{20}$

This short overview of the efforts of missionaries to impart Christian doctrine to the natives of Hispanic North America merely provides a quick look at the various types of studies that have developed in recent years as scholars come to grips with the nuance of the activity. The three articles included in this special issue each serve in their own way as another step in the developing field. They range geographically from the Yucatan peninsula to the borderlands. Chronologically they span the colonial period, but taken as a whole they provide some important insights into the actual performance and application of the missionary devices among the natives of the region.

Jonathan Truitt studies the use of music and theater by the missionaries in the very heart of the Aztec empire and colonial world, Tenochtitlan-Mexico. Using a wide variety of sources, Truitt reconstructs the musical and theatrical environment in the native region of San Josef in Mexico City in the colonial period. Looking at wills and other primary sources he teases out the use of music not just as a tool for evangelization, but also how it was adopted and adapted into the routine lives of everyday people. The music, that so attracted the natives to Christian ritual celebrations, also provided entry to religious drama. The celebration of the mass is in fact a highly stylized and ritualized form of theater. We know from many early sources how attractive the natives found Spanish theatrical presentations. The natives quickly took the genre and developed it further on their own. Drawing on numerous sources, Truitt is able to piece together a vision of the impact of religious drama on the neighborhood. One can clearly see that music and drama, although consciously used by the Spanish to attract and convert the natives, were taken over by the indigenous peoples and further developed within their own cultural environment.

Mark Christensen considers the use of ecclesiastical texts in two very different environments, among the Nahua and among the Maya. Christensen looks at non-

19. Bartolomé de Alva, A Guide to Confession Large and Small, 1634, edited and translated by Barry Sell and John F. Schwaller (Norman, OK: University of Oklahoma Press, 1999).

20. Hernando Ruiz de Alarcón, Treatise on the Heathen Superstitions That Today Live Among the Indians Native to this New Spain, 1629, transiated and edited by J. Richard Andrews and Ross Hassig (Norman, OK: University of Oklahoma Press, 1984). 


\section{Evangelization as Performance}

canonical Christian texts (texts "destitute of legitimate authority") and the place that they held in these two communities. In the case of the Nahua community, Christensen offers a sermon on the Conversion of Paul. The biblical conversion story is quite straight forward. Saul, a Jew who was also a Roman citizen, was active in persecuting the new Christian cult. Riding on the road to Damascus, he was stricken with blindness which only was lifted when he converted to the new sect and took the name Paul (Acts 9: 3-19). The Nahuatl account presented by Christensen has very little similarity to the canonical form. The Maya example is a variant of the biblical story of the creation of Adam. The account, however, varies in numerous ways from the Bible and is a wonderful conflation of stories and symbols. Christensen outlines the other types of Christian didactic material written in native languages and thus places these two texts in their context. His further analysis compares and contrasts the two and demonstrates how they each draw upon the specific cultural context from which they emerged. The crucial point is that these texts represent the natives of colonial Mexico attempting to integrate the Christian stories into their own cultural environment.

Kristen Dutcher Mann looks to the northern frontier of New Spain to see how natives and missionaries celebrated the feast of Christmas. As noted earlier, music has been the least studied of the arts of the evangelization. Mann draws upon an extremely wide range of sources to piece together to study the role that the Christian celebration of the birth of Christ had in the northern missions. Beginning with modern ethnographical information on the celebrations, she takes the reader back in time to the seventeenth and eighteenth century to see the origins of practices and then study them in the milieu of the evangelization. As with Central Mexico, music, dance, and theater all provided important points of contact to draw the natives into the Christian celebration. With the passage of time, too, these celebrations took on more of a local flavor, responding to the unique cultural environment within which they took root.

These three articles provide some important insights into the interface between native peoples and the Christian missionaries. In their examples one can see the negotiation between the missionaries and the natives as to what features of Christian worship would take hold and flourish and which might be relegated to a secondary position. These articles mark the continued development of the study of the local effect of larger theological and political themes in the colony. They are heirs of a revolution in historiography since 1974, and mark the continued development of research topics that look at the mundane and intimate aspects of everyday life in the colonial period. 